\title{
Dlouhodobá koncepce sportovního tréninku z pohledu tenisových expertů
}

\section{Long-term athletic development from the view of tennis experts}

\author{
Jan Pecha, Josef Dovalil
}

Fakulta tělesné výchovy a sportu Univerzity Karlovy v Praze

\begin{abstract}
Abstrakt
Př́spěvek analyzuje názory vybraných předních českých tenisových expertů na dlouhodobou koncepci sportovního tréninku $v$ tenise. Celkem bylo provedeno devět strukturovaných rozhovorü s osmi otevřenými otázkami, které měly identifikovat, potvrdit, př́padně kriticky posoudit možné cesty dosahováni nejvy̌̌ši tenisové výkonnosti. Výzkum se soustredil na tři tematické okruhy problému - charakteristické rysy tréninku, předpoklady úspěšných hráču a význam sportovnich soutěži. Výsledky ukázaly, že v dlouhodobém procesu tenisového tréninku je specializace od počátku nezbytná, avšak zároveň je nutné v tréninku mladých hráči akcentovat prožitkovost, radost, hravost a všestrannost. V rámci předpokladů úspěšných hráčů je nejčastěji zmiňována di̊ležitost psychických faktorü, podle hodnoceni experti̊ je umístění mezi nejlepšimi vrstevníky důležitým aspektem pro budouci vývoj hráče. Studie přináši poznatky, které mohou sloužit jako podněty pro tenisové svazy, trenéry, manažery a výzkumné pracovníky, zabývajici se problematikou identifikace, výběru a podporou talentü.
\end{abstract}

\section{Abstract}

This study analyses views of Czech tennis experts of the long-term athletic development in tennis. Based on nine structured open ended interviews is the aim of the study to identify, confirm and/or review the ways of achieving the top tennis performance. The study focuses on three topics of the problem - characteristic features of training, demands on successful players and importance of sport competitions. Results reveal the importance of specialization in the early age of children in the tennis training, and crucial is keeping principles of deliberate play and versatility as well. Psychological factors are frequently mentioned requirements for successful players. Based on the interviews with experts the ranking among top players in youth age categories is an important aspect for the player development. The research brings new and often required information for tennis federations, coaches, managers and researchers, dealing with the talent identification, selection and development.

Kličcová slova: dlouhodobá koncepce, raná specializace, trénink odpovídajicí vývoji, sportovní výkon, tenis, talent, soutěž

Key words: long-term athlete development, early specialization, multilateral development, sports performance, tennis, talent, competition

Tato studie byla realizována s podporou Výzkumného záměru MŠMT ČR MSM 0021620864 a s podporou projektu SVV 260116.

\section{ÚVOD}

Dlouhodobá koncepce tréninku (také dlouhodobý trénink, víceletý trénink, angl. long-term athlete development) je obvykle chápána jako promyšlená a zdůvodněná představa o cestách dosažení vysoké sportovní výkonnosti (např. Baker, 2003; Balyi \& Hamilton, 2003; Bar-Or, 1996; Lidor, Coté \& Hackfort, 2009; Ericsson, Krampe \& Tesch-Romer, 1993; Feige, 1973; Ford a kol, 2011; Hecimovich, 2004; Starkes \& Ericsson, 2003; 
Valik, 1975; Wiersma, 2000). Tedy představa o globálních i dílčích cílech, zaměření, posloupnosti a návaznosti tréninku, jeho obsahu, zatížení i přístupu od počátku sportování do ukončení sportovní kariéry. Názor na uvedené problémy není jednotný. Jeho konkrétní podobu ovlivňuje mj. míra talentovanosti sportovců. Vedle talentu však má mimořádnou důležitost dlouholetý a systematický trénink, stejně tak samotné sportovní soutěže.

V předkládané studii jsme se pokusili na základě analýzy názorů vybraných tenisových expertů zjistit, jaký je k těmto otázkám př́stup v českém tenisu.

Cílem bylo identifikovat, potvrdit, př́ípadně kriticky posoudit možné cesty dosahování nejvyšší tenisové výkonnosti. Výzkum se soustředil na tři tématické okruhy problému dlouhodobé koncepce sportovního tréninku v tenise - charakteristické rysy tréninku, předpoklady úspěšných hráčů a význam sportovních soutěží.

\section{CHARAKTERISTICKÉ RYSY TRÉNINKU}

Základy pozdější výkonnosti se vytvářejí už ve školním věku. Je tudíž vhodné, aby perspektiva jednotlivce byla rozpoznána co nejdříve. Zkušenosti i teoretické poznatky svědčí o tom, že důležitá je jak určitá míra talentovanosti, tak i mnohaletý pravidelný a systematický trénink. Analýzy tréninku a sportovního vývoje (např. Bompa, 2000; Brown, 2001; Dovalil a kol., 2009, Schnabel, Harre \& Krug, 2008) upozorn̆ují v tomto smyslu na nezbytnost budování základů pro pozdější vrcholové výkony již v dětském věku. Promyšlená koncepce by proto měla obsáhnout celoživotní sportovní kariéru.

V literatuře o sportovním tréninku se problém dlouhodobé koncepce vymezuje ve dvou podobách: jako přístup preferující ranou specializaci a trénink odpovídající individálnímu vývoji (např. Baker, 2003; Bompa, 2000; Bompa \& Haff, 2009; Brown, 2001; Dovalil a kol., 2009; Joch, 1997; Starkes \& Ericsson, 2003; Schnabel, Harre \& Borde, 1997; Schnabel, Harre \& Krug, 2008). Podstatu tohoto členění uvádíme s ohledem na strategii a obsah tréninku, zatěžování a psychologické rysy tréninku v tabulce 1. Je zřejmé, že oba dlouhodobé př́istupy se ve zmíněných aspektech odlišují.

Tabulka 1: Charakteristické rysy tréninkové koncepce rané specializace a tréninku odpovídajícího vývoji (Dovalil a kol., 2009; Perič, 2006)

\begin{tabular}{|l|l|}
\hline \multicolumn{1}{|c|}{ RANÁ SPECIALIZACE } & \multicolumn{1}{|c|}{ TRÉNINK ODPOVÍDAJící VÝVOJI } \\
\hline \multicolumn{2}{|c|}{ Strategie tréninku } \\
\hline $\begin{array}{l}\text { Vysoká výkonnost co nejdřive, plánovitý trénink si klade } \\
\text { za cíl co nejrychleji dosáhnout úspěchu }\end{array}$ & $\begin{array}{l}\text { Výkonnost přiměřená věku, nejvyšší výkon jako } \\
\text { perspektivní cíl, dětství a mládí je přípravnou etapou }\end{array}$ \\
\hline \multicolumn{2}{|c|}{ Obsah tréninku } \\
\hline $\begin{array}{l}\text { Cenu má jen to, co směřuje rychle k cíli, úzké zaměření } \\
\text { na specializaci (jednostrannost) }\end{array}$ & Vědomý podíl všestrannosti \\
\hline \multicolumn{2}{|c|}{ Velikost zatížení } \\
\hline $\begin{array}{l}\text { Až na hranici únosnosti, neúměrné nároky na nevyzrálé } \\
\text { jedince }\end{array}$ & $\begin{array}{l}\text { Zřetel na stupeň individuálního vývoje, postupné a } \\
\text { pozvolné stupňování nárokủ }\end{array}$ \\
\hline \multicolumn{2}{|c|}{ Psychologické rysy tréninku } \\
\hline $\begin{array}{l}\text { Tvrdost, cílevědomost, v tréninku psychické momenty } \\
\text { charakteristické pro práci dospělých: napětí, vážnost, } \\
\text { vyhraněná racionalizace, tlak na výkon }\end{array}$ & $\begin{array}{l}\text { Trénink odpovídající mentalitě věkového stupně, } \\
\text { omezování tlaku na výkon, aktuální výkonnostní cíle } \\
\text { nejsou výlučné, radost, hravost, uvolněnost, bohatství } \\
\text { prožitků, přiměřené ocenění }\end{array}$ \\
\hline
\end{tabular}

Zkušenosti z řady sportů naznačují, že rekordních výkonů lze dosáhnout jak ranou specializací, tak i tréninkem, který bere větší ohled na vývojové zvláštnosti jedinců (např. Dovalil a kol., 2009; Feige, 1973; Schumacher, 2007). Otázkou zůstává, za jakou cenu, s jakými důsledky vývojovými, zdravotními, psychickými (např. Hecimovich, 2004; Wiersma, 2000).

V tenise se tématem dlouhodobé koncepce tréninku zabývali např. Roetert, Reid \& Crespo (2005), kteří ve své studii uvádí specifické znaky tenisu v oblasti periodizace, problematice ř́zení tréninku a zatížení. Mnozí autoři se zaměřili na dílčí aspekty dlouhodobé koncepce tréninku, zejména na charakteristiky jednotlivých složek sportovního výkonu hráčů. Např. Unierzyski (2005) sledoval tuto problematikou u hráčů do 12 a 14 let, Molina (2005) u hráčů juniorského týmu ITF a Morris (2005) u hráčů do 18 let. Analýzou dlouhodobé koncepce 
tréninku v tenise - se zaměřením na dosahování vrcholných výkonů mužů (ATP) a žen (WTA) - zabývali Roetert \& McEnroe (2005), Porta \& Sanz (2005), Martens \& Maes (2005) nebo Reid, Quinlan \& Morris (2010).

\section{Předpoklady úspěšných hráčů}

Vysoká sportovní výkonnost souvisí z velké části s mírou talentovanosti. Pohled na talent obvykle vychází z modelu budoucího sportovce - deskripce požadavků sportovního výkonu (v naší literatuře se hovoří o struktuře sportovního výkonu, založené na analýze jeho složek, resp. faktorů, komponent nebo determinant, napřs. Dovalil a kol., 2009; DTB, 1996) a z toho odvozených požadavků na talentovaného sportovce, bez kterých je jakákoliv predikce, neboli předpověd' budoucí výkonnosti, velmi obtížná (Perič, 2006).

Skladba psychofyzických předpokladů úspěšných tenisových hráčů zahrnuje jak endogenní - vrozené dispozice a vlastnosti (Bompa, 2000; Brown, 2001; Dovalil a kol., 2009; DTB, 1996; Schnabel, Harre \& Krug, 2008; Grosser \& Schönborn, 2008), tak exogenní činitele - vliv prostředí a výchovy (De Bosscher, De Knop \& Heyndels, 2003; Perič, 2006), které by měli mít budoucí hráči širší tenisové špičky.

\section{Význam sportovních soutěží}

V dlouhodobé koncepci sportovního tréninku hrají také důležitou roli sportovní soutěže. Ne všechny mají přitom stejný význam. V souladu s uznávaným názorem na smysl soutěží (např. Hohmann, Lames \& Letzelter, 2010; Thiess \& Tschiene, 1999; Tschiene, 1994) je třeba rozlišovat starty hlavní jako cíle tréninku v nejdůležitějších soutěžích vyžadujících maximální soustředěný výkon (např. vrcholné mezinárodní turnaje, olympijské hry, mistrovství republiky) a starty pomocné víceméně jako prostředky tréninku (např. zkušenost ze sportovního boje pro prověření úderů, seznámení se s prostředím atp.).

Soutěže představují velmi intenzivní podněty, vyžadují reagovat maximálním úsilím, psychická stránka zatížení je často větší než tělesná, je třeba koncentrovat síly, ovládnout vzrušení apod., to vše nelze získat pouze v tréninku. Nedostatek závodních startů může mít za následek nezkušenost a nedostatečné využití toho, co bylo získáno tréninkem. Na druhé straně nadměrná účast v soutěžích sice vede k rozšiřování soutěžní zkušenosti, během soutěže však nelze účinně korigovat a odstraňovat chyby, přehnané soutěžení snižuje možnost seriózního tréninku. Racionální přístup proto usiluje o úzké propojení a sladění soutěží a tréninku, jen tak se dá dosáhnout skutečného sportovního úspěchu.

Smysl sportovních soutěží dětí a mládeže spočívá v tom, že si nekladou bezprostřední výkonnostní cíle, ale jsou součástí perspektivní přípravy mladších kategorií. Výsledky dosahované na sportovních soutěžích nejen vyjadřují úspěšnost předchozí př́ípravy, ale stávají se současně zdrojem další motivace pro pokračování tréninku. Soutěže jsou situovány převážně do závodního období ročního tréninkového cyklu a přirozeně završují proces sportovního tréninku (Dovalil a kol., 2009).

Soutěžní utkání a turnaje jsou přirozeně považovány za součást rozvoje tenistů (Crespo a kol., 2003; MacCurdy, 1999). Na území České republiky spadá koordinace pořádání turnajů pod Český tenisový svaz (dále jen ČTS). Mezinárodní okruhy turnajů jsou spravovány Tennis Europe (dále jen TE), Mezinárodní tenisovou federací (dále jen ITF) a organizacemi profesionálů ATP (Association of Tennis Professionals) a WTA (Women‘s Tennis Association). V souvislosti s umístěním hráčů na žebříčku se považuje prvních sto hráčů a hráček, označovaných jako top 100, na okruzích ATP a WTA, za širší tenisovou špičku. Tento soubor je považován za základní model nejvyšší výkonnostní úrovně (Vaverka \& Černošek, 2007). Dosažení umístění v top 100 na světových žebříčcích ATP a WTA je považováno za významný úspěch v profesionálním tenise (McCraw, 2011, 2012).

Z důvodu zvýšení propagace a konkurenceschopnosti tenisu vůči ostatním sportům představila Mezinárodní tenisová federace v roce 2007 kampaň Play and Stay. Hlavní myšlenkou kampaně je představit tenis jako sport, ve kterém je možnost hrát utkání již během první tréninkové jednotky. Cílem je tak umožnit zejména dětem hrát tenis již od nízkého věku na menším dvorci, s nižší sítí, menšími a lehčími raketami a míči s nižším tlakem. Změny v pravidlech týkající se hráčů do 10 let byly schváleny v roce 2010 (ITF, 2012), v roce 2012 bylo do kampaně zapojeno přes 160 zemí světa. Kampaň ITF Play and Stay zahrnuje programy pro hráče věkových kategorií do 10 let, 11-17 let a dospělých (Tennis Xpress), dále mezinárodní programy systému hodnocení úrovně hráčů (International Tennis Number) a hodnocení klubové úrovně (Tennis Play and Stay Clubmark).

Na území České republiky spadá koordinace pořádání turnajů pod Český tenisový svaz. V rámci soutěží se rozlišují věkové kategorie minitenis (6-7 let), babytenis (8-9 let), mladší žactvo (10-12 let), starší žactvo 
(13-14 let), dorost (15-17 let) a dospělí. Základní filozofickou myšlenkou projektu Českého tenisového svazu minitenis a babytenis je na základě principů kampaně Play and Stay hravým způsobem přilákat děti předškolního a mladšího školního věku k tenisu. Soutěživost dětí a ambice rodičů však postupem času tuto filozofii často popírají, a může tak docházet k nadměrnému tréninkovému a turnajovému zatížení dětí již ve věku do 10 let.

\section{METODIKA}

K řešení stanoveného cíle jsme použili strukturovaný rozhovor s osmi otevřenými otázkami (tabulka 2). Tento typ rozhovoru byl použit z důvodu minimalizace variace otázek kladených dotazovanému. Byla tak redukována pravděpodobnost, že se data získaná v jednotlivých rozhovorech budou výrazně strukturně lišit (Hendl, 2005).

Otázky se týkaly třech okruhů problému dlouhodobé koncepce sportovního tréninku v tenise. Zajímali jsme se o názory na charakteristické rysy tréninku, předpoklady úspěšných hráčů a na význam sportovních soutěží. Otázky reflektovaly zkušenosti i znalosti vybraných expertů.

Tabulka 2: Dlouhodobá koncepce sportovního tréninku v tenise - tématické okruhy a otázky rozhovorů

\begin{tabular}{|l|l|}
\hline \multicolumn{1}{|c|}{ TÉMATICKÉ OKRUHY } & \multicolumn{1}{c|}{ OTÁZKY } \\
\hline $\begin{array}{l}\text { Charakteristické rysy } \\
\text { tréninku }\end{array}$ & $\begin{array}{l}\text { Jak vnímáte současnou situaci výkonnostního vývoje tenistů v ČR v souvislosti se } \\
\text { zavedením programu ITF Play and Stay, a to zejména z pohledu různých vlivů na } \\
\text { sportovní výkon? } \\
\text { Jak se díváte na ranou specializaci v tenise, máte doporučení týkající se dlouhodobé } \\
\text { koncepce? }\end{array}$ \\
\hline Předpoklady úspěšných hráčù & $\begin{array}{l}\text { Jsou podle Vás nějaké společné charakteristiky, znaky nebo vlastnosti úspěšných } \\
\text { hráčŭ, resp. hráču širší tenisové špičky, které lze pozorovat již v mládežnickém věku? } \\
\text { Jakou roli má pro budoucího hráče širší tenisové špičky ATP a WTA zařazení v } \\
\text { reprezentačním družstvu do 14 let a v TSM? }\end{array}$ \\
\hline Význam sportovních soutěží & $\begin{array}{l}\text { Jak byste na základě pro- a retrospektivní analýzy umístění hráčů hodnotil jejich } \\
\text { úspěšnost v prosazení se do širší tenisové špičky - resp. jakou důležitost v rámci } \\
\text { vývoje hráče přisuzujete umístění na CŽ a TE, resp. ITF ve vztahu k prosazení se na } \\
\text { ATP a WTA? } \\
\text { Jak ovlivñuje hráče absolvování turnajů v mládežnických kategoriích? } \\
\text { Jak byste hodnotil současný a budoucí význam soutěží ČTS, TE a ITF (Juniors a Pro } \\
\text { Circuits) a jejich věkové kategorie pro budoucí hráče širší tenisové špičky ATP a } \\
\text { WTA? } \\
\text { Myslíte si, že nastavený systém soutěží ČTS, TE a ITF má pozitivní vliv na prosazení } \\
\text { talentovaných hráčủ do širší tenisové špičky ATP a WTA a proč? }\end{array}$ \\
\hline
\end{tabular}

Vysvětlivky: ITF - Mezinárodní tenisová federace, ČTS - Český tenisový svaz, TE - Tennis Europe, TSM Tréninkové středisko mládeže, CŽ - celostátní žebříček, ATP - Association of Tennis Professionals, WTA - Women's Tennis Association

Rozhovory byly vedeny s devíti tenisovými experty (R 1-9) z Mezinárodní tenisové federace (ITF, 1), Českého tenisového svazu (ČTS, 1), Tréninkových středisek mládeže (TSM, 2), Sportovních center mládeže (SCM, 2), Davis Cupu (DC, 2) a Fed Cupu (FC, 1), a to v období listopad-prosinec 2012. Délka rozhovorů se pohybovala $v$ rozpětí 5:31-13:30 minut. Před každým rozhovorem jsme s respondenty uskutečnili krátkou diskuzi ke zkoumanému tématu, resp. byl vymezen tématický rámec.

Data byla analyzována na základě tématické analýzy (Boyatzis, 1998). První fází práce s materiálem byla jeho organizace - označení, roztřídění a redukce dat. V druhé fázi proběhla vlastní interpretace, která vedla $\mathrm{k}$ popisné a explanatorní zprávě o zkoumané oblasti. Z hlediska způsobů transkripce textového materiálu byla použita doslovná transkripce (Mayring, 1990). Text byl přenesen do spisovného jazyka, byl očištěn od dialektu, upraven stylisticky, a to zejména $z$ důvodu soustředění především na obsahově-tematickou rovinu. Informátor vystupuje v interview jako expert. Záznam byl pořízen na diktafon Apple iPhone 4S. Kvalitativní analýza dat byla provedena $v$ textovém editoru OpenOffice.org 3.3.0.

\section{VÝSLEDKY A DISKUSE}

V rozhovorech s 9 respondenty bylo celkem v odpovědích zaznamenáno 203 významových jednotek. Ty byly následně rozřazeny do 16 kategorií ve 3 tematických okruzích. 


\section{Charakteristické rysy tréninku}

Názor expertů související s programem ITF ilustrují následující formulace z odpovědí:

„Program ITF Play and Stay je unikátní projekt, který má úžasnou odezvu v tenisových velmocích jako je Austrálie, Francie, Velká Británie, protože pomáhá rozšiřovat základnu tam úplně dole ... je založen na ohromných principech." (R9)

„Pozitivním aspektem je, že děti můžou spolu začít dřiv soutěžit. A z mého pohledu to má samožrejmě $i$ negativni stránku. Myslím si, že technika hráčů je trochu ovlivněna tím brzkým použiváním zkrácených raket, krátkého kurtu; že to má trochu negativní vliv na techniku, protože někteři hráči potom tu techniku neupraví." (R4)

Podle hodnocení šesti expertů je program ITF Play and Stay př́nosem pro současný tenis, ale obsahuje také negativní prvky, což uvedlo pět dotazovaných. Mezi pozitivní aspekty řadí rovnoměrný vývoj jedince nebo konkurenceschopnost tenisu vůči ostatním sportům - z důvodu možnosti dřívějšího zapojení dětí do zápasů. To je ve shodě s původními myšlenkami kampaně Mezinárodní tenisové federace propagující program ITF Play and Stay (De Boer, 2010; ITF, 2012; Miley, 2010).

Negativně experti vnímají eventuální nadměrný psychický stres ze zápasů ve velmi nízkém věku dětí, jednostranné zaměření hráčů a možnost častějšího výskytu zranění v pozdějších letech jako důsledku rané specializace. Možná rizika spojená s ranou specializací uvádí ve své přehledové studii např. Hecimovich (2004), který zmiňuje v této souvislosti negativní vlivy, které mohou diagnostikovat pohledy anatomie, fyziologie, psychologie nebo sociologie.

Důležitou roli hraje podle čtyř respondentů primární zaměření na techniku - zdokonalování pohybových dovedností v tréninku hráčů do 10 let, především úderovou techniku a pohyb po dvorci. Takovou orientaci preferuje i řada autorů (např. Bollettieri, 2001; Crespo \& Miley, 2002; Kriese, 1997), podle Schönborna (1993) nejvíce ovlivňuje právě úroveň pohybových dovedností výsledný výkon hráčů ve věku do 13 let.

Sedm oslovených expertů se shoduje v tom, že úzké zaměření na specializaci v raném věku zvyšuje riziko negativních důsledků ve výkonnostním vývoji hráčů. Ve shodě s některými autory (např. Cote, 1999; Cote \& Hay, 2002; Petlichkoff, 1993) by měl být spíše kladen důraz na jeden z hlavních principů tréninku dětí, označovaný jako herní princip, tedy omezování tlaku na výkon v utkáních, zdůrazňování prožitku a radosti z pohybu, a pestrou činnost, resp. všestrannost (Bompa, 2000; Schnabel, Harre \& Krug, 2008). Podle zjištěných expertních odpovědí je:

„....tenis jako sport je nesmírně náročný ... raná specializace je rozhodně potřebná ... ano raná specializace, ale těmi správnými formami." (R9)

Experti hovoří také o možném negativním vlivu rodičů na vývoj hráče, zejména jejich nepřiměřených nárocích, brzkém tlaku na výkon. $\mathrm{O}$ důležitosti vlivu rodiny na výkonnostní vývoj talentovaných sportovců vypovídá řada autorů (napr. Bloom, 1985; Brustad, 1993; Hellstedt, 1995; Woolger \& Power, 1993; Young, 2011). Např́klad Coté (1999) ve své studii analyzuje dynamiku rodiny v každé vývojové fázi sportovce etapách základního, specializovaného a vrcholového tréninku. Výsledky Goulda a kol. (2008) ukázaly, že podle názorů tenisových trenérů měla většina rodičů na hráče juniorských kategorií pozitivní vliv pokud jde o jejich chování a postoje, byl vyzdvižen i důraz na jejich rozvoj a podporu. Genevois (2011) a Bois, Lalanne \& Delforge (2009) uvádí ve svých studiích pozitivní (zabezpečení psychické a finanční podpory, logistické zajištění) a negativní (tlak na vítězství, tenis prioritou před ostatními aktivitami) znaky chování rodičů mladých tenistů. Podobný názor vyslovili i dotazovaní experti.

Bohužel reálná situace je dnes dost hektická. A ty vlivy jsou spiš negativní. U některých dětí se jedná, bych řekl, o ranou specializaci a šilení rodičů... nejedná se tam o žádný všestranný pohyb, jde jen o jednostranné zaměreni." (R5)

\section{Předpoklady úspěšných hráčů}

Všech devět oslovených expertů v rozhovorech potvrzuje v souladu s literaturou (např. Dovalil, 2009; DTB, 
1996; Grosser \& Schönborn, 2008; Schnabel, Harre \& Krug, 2008; Schnabel, Harre \& Borde, 1997) shodně faktory sportovního výkonu, které charakterizují úspěšného hráče - psychické, taktické, kondiční, technické a somatické. Nejčastěji ovšem hovoří (osm respondentů) o faktorech psychologických - např. intelektuálních schopnostech nebo motivaci (vítězný charakter hráče, psychická odolnost, morálně-volní vlastnosti, sebevědomí).

„... v prvni radě jsou to určité povahové vlastnosti. To znamená ctižádost, vưbec jeho systém života, organizace vlastního života už třeba $v$ dětství. Za druhé somatotyp toho člověka, jeho pohybové schopnosti, které určitě lze vypozorovat v nějakém raném tenisovém věku a které jsou svým zpiosobem determinující pro ten dalši vývoj." (R1)

„... ti lepši hráči dokážou řešit situace jinak než ti ostatni hráči. Tím ziskávaji převahu v těch zápasech, možná jsou i víc odolnějši psychicky." (R5)

„....musí mít údery, nějaký úder, když se to vezme z technického hlediska, který je „,smrtelný”...” (R3)

„, Tenis se nauči skoro každý, ale vyhrávat se nenauči všichni, samozrejejě. Když je postavíme všechny na stejnou startovni čáru a budou to umèt stejně, budou trénovat stejně hodin a půjdou dopredu, tak někdo bude lepši a někdo horšil.” (R3)

Ukazatelem budoucích úspěšných hráčů je podle jednoho respondenta také zvládnutí jejich přechodu do vyšší věkové kategorie:

,... když jsem pracoval na ČTS, došel jsem $k$ závěru, že ti mladí hráči v tom přechodu z kategorie do 14 let do té kategorie dalši do 18 let velmi rychle zvládli ten prechod a již v tom prvním roce ve věku kolem 15 let se začli prosazovat, jednoznačně prosazovat už mezi těmi 18letými... Tak to bylo charakteristické pro všechny ty hráče a hráčky, kteři potom jako se dostali vysoko do stovky ATP a WTA. ...něco podobného je i v tom prechodu z juniorského do profesionálního tenisu." (R9)

Důležitým aspektem ve výkonnostním rozvoji hráčů je podle sedmi expertů také vytvoření dobrých tréninkových podmínek, resp. zabezpečení tréninkového procesu odpovídajícího výkonnostní úrovni hráče, podobnou zkušenost dokládá řada autorů (Crespo \& Miley, 2002; De Bosscher, De Knop \& Heyndels, 2003; Perič, 2006). Rozumí se tím nap̌r. trénink pod vedením kvalifikovaného trenéra, zajištění sparringu, vytvoření přijatelného konkurenčního prostředí, finanční a materiální podpora hráče, zajištění kondičního tréninku a fyzioterapie, pravidelná kontrola zdravotního stavu hráče.

Pro osm respondentů je zařazování hráčů do Tréninkového střediska mládeže (TSM) nebo reprezentace věkové kategorie U14 z hlediska výkonnostního růstu hráče prŕínosné, podle čtyř respondentů však nemusí být rozhodující:

„Zar̆azeni do Tréninkového střediska mládeže je určitě dobře, protože to znamená jedinou věc, a to, že se hráč dostane do tréninku nebo do společnosti těch lepšich anebo těch nejlepšich v těch svých ročnících, nebo $v$ těch svých oblastech." (R2)

„Myslím si, že je to výborná motivační složka a navíc reprezentačni týmy do 14 let absolvovali hráči jako byl Djokovič, Nadal a podobni velikáni světového tenisu." (R8)

„V reprezentačním družstvu do 14 let si myslím, že zařazeni hráče význam má, protože se potká už na světové nebo evropské úrovni s hráči z jiných států ...” (R1)

„Já si myslím, že to nemá žádnou roli. Někdo tam je, se prosadí, a ti co tam nejsou, tak se v tom tenise se můžou také prosadit, takže to neni určitě rozhodujici pro budoucí vývoj hráče." (R5)

\section{Význam sportovních soutěží}

Podle hodnocení osmi expertů je umístění mezi nejlepšími vrstevníky důležité pro budoucí vývoj hráče. Nesmí však jít o samoúčelné dosahování předního umístění na žebříčku, za důležitý experti považují způsob dosažení umístění hráče.

„Já si myslím, že musí být ve špičce, musi být třeba do desátého místa... Ale nesmí mu utéct špička.” (R3) 
„Sbírání bodi̊ na turnajich za účelem umistěni na celostátním žebřičku musí být bráno rozumně...” (R1)

„,...myslím si, že by v těch mládežnických kategoriich ty děti měly být do pátého desátého místa." (R6)

„Z mého pohledu ale není úplně nutné, aby hrál jeden turnaj za druhým, protože tam se musí opravdu rozumně volit ten poměr mezi turnaji a tréninkem..., protože pakliže se přežene počet turnajü, není čas na př́pravu, tak ten hráč se nevyvíji v dalšich segmentech hry, které v těch mládežnických turnajích většinou nepouživá.” (R4)

„Pro mě je spiš důležité, když už tedy ten hráč turnaje Tennis Europe nebo ITF hraje, tak to není konečný žebřiček jako to, jakým stylem ho dosáhl ... musel bych se podívat, kde ty turnaje absolvoval ... uhrát body na turnajich např́klad v Jižni Americe a v Asii je daleko snazší." (R4)

V tomto směru např. MacCurdy (2006) upozorňuje na důležitost dosažení určité minimální výkonnostní úrovně z hlediska výsledků hráče v každé etapě sportovního tréninku pro pozdější možnost dosažení vrcholné výkonnosti. V souladu s literaturou (Choutka \& Dovalil, 1991) je pak také doporučen ve věkových kategorích U10 důraz na akcentování soutěží družstev před soutěžemi jednotlivců; dále i event. snížení počtu turnajů v kategoriích U12 a možné zavedení žebříčku až v kategorii U14.

Rozdílně se respondenti staví k celostátnímu žebříčku ČTS a žebříčku TE jako vypovídající hodnotě o vývoji hráče:

„, Tak z hlediska umistění na celostátním žebřičku si myslím, že je to určitě vypovídající hodnota toho, jak se daný hráč vyvíjí..." (R4)

Za nejvyšší vypovídající hodnotu se považují juniorské žebříčky ITF, shoduje se na tom šest respondentů. Tento názor je v souladu s výsledky některých studií (např. Miley \& Nesbitt, 1995; McCraw, 2011, 2012; Reid a kol., 2005, 2007; Reid, 2009), zabývajících se problematikou dlouhodobého vývoje umístění hráču, které ukazují na vysokou úspěšnost prosazení předních juniorů žebříčku ITF mezi profesionálními hráči ATP a WTA.

Z analýzy rozhovorů vyplývá, a to v souladu s literaturou (např. Choutka \& Dovalil, 1991; Hohmann, Lames \& Letzelter, 2010), že účast v soutěžích je pro výkonnostní růst sportovců nezbytná. Důležité jsou však podle čtyř expertů také respektování přiměřené tréninkové a turnajové zátěže, a to vzhledem $\mathrm{k}$ věku a výkonnostní úrovni hráče, dále pak postupné kroky při dosahování umístění a brzké prosazení na žebříčcích ITF, ATP a WTA:

„, Mezinárodní turnaje bych bral jako zkušenost vůbec hrát venku, a doporučuju začínat co nejdř́ve s turnaji ATP a WTA... na druhou stranu jít postupnými kroky-napřed vyhrávat turnaje v Česku, pak začit jezdit ven..." (R6)

„,...já si myslím, že je to v pořádku, že to je rozdělené do 12 , do 14 a do 18 ... A doporučuju prostě ty turnaje ITF, co nejdřvive zkoušet kategorie mužů a žen." (R6)

Absolvování turnajů podle všech devíti respondentů pozitivně determinuje výkonnostní růst a herní úroveň hráčů. Odpovídá to výše citovanému názoru, že teprve v soutěžích se může sportovní výkon upevňovat a zdokonalovat jako ucelený komplex na odpovídající úrovni intenzity včetně působení vnějších vlivư. Účast v soutěžích patři k významným formám dlouhodobě koncipovaného zvyšování sportovní výkonnosti. Nelze proto vytvářet dělicí čáru mezi tréninkový proces a soutěže, naopak je nutné pochopit jejich vzájemnou souvislost a podmíněnost. Doporučením může být uvážené plánování turnajových bloků, tréninky a analýza zápasů při turnajích.

Dosavadní systém soutěží ČTS, TE a ITF považuje všech devět respondentů za optimální. Možnou úpravu vidí ve zrušení kategorie U16 v soutěžích pořádaných Tennis Europe nebo snížení horní hranice juniorské kategorie ITF z 18 na 17 let.

\section{ZÁVĚR}

Předkládaná studie je příspěvkem $\mathrm{k}$ problému dosahování vysoké sportovní výkonnosti tenistů v dlouhodobém, mnohaletém horizontu. V tematických okruzích dlouhodobé koncepce sportovního tréninku byly s využitím rozhovorů s tenisovými experty analyzovány jejich názory na charakteristické rysy tréninku, předpoklady úspěšných hráčů a význam sportovních soutěží. 
Zjištění získaná na základě strukturovaných rozhovorů s otevřenými otázkami přinášejí podněty a argumenty ve smyslu prokázání určitých trendů a tendencí v tenise a následně podpory možných koncepcí dlouhodobého tréninku - rané specializace a tréninku odpovídajícího vývoji. Byly shromážděny názory na předpoklady budoucích úspěšných hráčů, které je možné pozorovat již ve věku žákovských kategorií. Experti se vyjadřovali rovněž k významu sportovních soutěží ve vztahu k pozdějšímu prosazování hráčů na mezinárodních žebříčcích ATP a WTA.

Výsledky naznačily, že $\mathrm{v}$ dlouhodobém procesu tenisového tréninku považují experti přiměřený specializovaný trénink od prvních let za potřebný, avšak zároveň nelze opomíjet důležitost všestrannosti včetně uplatnění př́istupu založeného na herním principu (omezení tlaku na výkon, zdůraznění pozitivních prožitků). Kampaň Mezinárodní tenisové federace Play and Stay je v tomto smyslu podle většiny respondentů přínosná pro současný tenis, podle některých však obsahuje negativní prvky.

Mezi předpoklady budoucích úspěšných hráčů experti řadí různé endogenní a exogenní faktory sportovního výkonu, nejčasteji je zmiňována důležitost psychických faktorů - intelektuálních schopností nebo motivace. Dále pak zvládnutí přechodu hráče do vyšší věkové kategorie. Zařazení hráče do Tréninkového střediska mládeže nebo reprezentace jsou př́nosné pro jeho výkonnostní růst, nemusí však být rozhodující.

Podle hodnocení expertů představuje umístění mezi nejlepšími vrstevníky důležitý aspekt pro budoucí vývoj hráče, je nutné však brát v úvahu respektování tréninkové a turnajové zátěže vzhledem k věku a výkonnostní úrovni hráče. Dosavadní systém soutěží ČTS, TE a ITF dotazovaní experti považují za optimální.

\section{LITERATURA}

Baker, J. (2003). Early Specialization in Youth Sport: requirement for adult expertise? High Ability Studies, 14(1), 85-94.

Balyi, I., \& Hamilton A. (2003). Long-term Athlete Development Update: Trainability in Childhood and Adolescence. Faster, Higher, Stronger, 20, 6-8.

Bar-Or, O. (1996). The Child and Adolescent Athlete. London: Blackwell Scientific Publications.

Bloom, B. S. (1985). Developing Talent in Young People. New York: Ballantine Books.

Bois, J., Lalanne, J., \& Delforge, C. (2009). The influence of parenting practices and parental presence on children's and adolescent's precompetitive anxiety. Journal of Sports Sciences, 27, 995-1005.

Bollettieri, N. (2001). Bollettieri's Tennis Handbook. Champaign: Human Kinetics.

Bompa, T. O. (2000). Total training for young champions. Champaign: Human Kinetics.

Bompa, T. O., \& Haff, G. G. (2009). Periodization: theory and methodology of training. Champaign: Human Kinetics.

Boyatzis, R. E. (1998). Transforming qualitative information. Thousand Oaks, CA: Sage.

Brown, J. (2001). Sports Talent. Champaign: Human Kinetics.

Brustad, R. J. (1993). Who will go out and play? Parental and psychological influences on children's attraction to physical activity. Pediatric Science, 5, 210-223.

Coté, J. (1999). The Influence of the Family in the Development of Talent in Sport. The Sport Psychologist, 13, 395-417.

Coté, J., \& Hay, J. (2002). Children's involvement in sport: A developmental perspective. In J.M. Silva, \& D.E. Stevens (Eds.) Psychological foundations of sport (pp. 484-502). Boston: Allyn \& Bacon.

Crespo, M., \& Miley, D. (2002). Tenisový trenérský manuál 2. stupně. Olomouc: Univerzita Palackého.

Crespo, M., Reid, M., Miley, D., \& Atienza, F. (2003). The relationship between professional tournament structure on the national level and success in men's professional tennis. Journal of Science and Medicine in Sport, 6, 3-13.

De Boer, J. (2010). How the tennis industry will be affected by Tennis 10s. ITF Coaching and Sport Science Review, 51(18), 11-12.

De Bosscher, V., De Knop, P., \& Heyndels, B. (2003). Comparing Tennis Success Among Countries. International Sports Studies, 25(1).

Deutscher Tennis Bund (DTB). (1996). Tennis-Lehrplan Band 2 - Unterricht \& Training. München, Wien, Zürich: BLV.

Dovalil, J. a kol. (2009). Výkon a trénink ve sportu. Praha: Olympia.

Ericsson, K. A., Krampe, R. T., \& Tesch-Römer, C. (1993). The role of deliberate practice in the acquisition of expert performance. Psychological Review, 3, 363-406. 
Feige, K. (1973). Vergleichende Studien zur Leistungsentwicklung von Spitzensportlern. Schorndorf: Karl Hofmann.

Ford, P., Croix, M., Lloyd, R., Meyers, R., Moosavi, M., Oliver, J., Till, K., \& Williams, C. (2011). The LongTerm Athlete Development model: Physiological evidence and application. Journal of Sports Sciences, 29(4), 389-402.

Genevois, C. (2011). The role of parents in the training of beginner tennis players. ITF Coaching and Sport Science Review, 55(19), 26-27.

Gould, D., Lauer, L., Rolo, C., Jannes, C., \& Pennisi, N. (2008). The Role of Parents in Tennis Success: Focus Group Interviews With Junior Coaches. The Sport Psychologist, 22, 18-37.

Grosser, M., \& Schönborn, R. (2008). Training im Kinder- und Jugendtennis. Aachen: Meyer und Meyer.

Hecimovich M. (2004). Sport specialization in youth: a literature review. JACA, 41(4), 32-42.

Hellstedt, J.C. (1995). Invisible players: A family system model. In S.M. Murphy, Sport Psychology Interventions (pp.117-146). Champaign, IL: Human Kinetics.

Hendl, J. (2005). Kvalitativní výzkum: základní metody a aplikace. Praha: Portál.

Hohmann, A., Lames, M., \& Letzelter, M. (2010). Úvod do sportovního tréninku. Olomouc: Univerzita Palackého.

Choutka, M. \& Dovalil, J. (1991). Sportovní trénink. Praha: Olympia a Karolinum.

International Tennis Federation (2012). The 10-and-under competition Rule Change [online]. Prístup dne 11.11.2013, z http://www.tennisplayandstay.com/tennis10s/rule-changes/the-10-and-under-competition-rulechange.aspx.

Joch, W. (1997). Das sportliche Talent: Talenterkennung - Talentförderung - Talentperspektiven. 3. vydání. Aachen: Meyer \& Meyer.

Kriese, C. (1997). Coaching Tennis. Indianapolis: Masters Press.

Lidor, R., Coté, J., \& Hackfort, D. (2009). ISSP Position stand: To test or not to test? The use of physical skill tests in talent detection and in early sport development. Int J Sport Exercise Psychol, 9, 131-46.

Mayring, P. (1990). Einführung in die qualitative Sozialforschung. München: Psychologie Verlag Union.

MacCurdy, D. (1999). Key elements for player development: Challenges to American tennis, In M. Crespo, D.

Miley, M. Reid (Eds.). Top Tennis Coaching: Proceedings of the 11th ITF Worldwide Coaches 'Workshop (pp. 10-12). London: ITF.

Martens, S., \& Maes, C. (2005). Periodisation for professional female tennis players. ITF Coaching and Sport Science Review, 13(36), 13-15.

McCraw, P. D. (2011). Making the Top 100: ITF Top 10 junior transition to Top 100 ATP tour (1996 - 2005). ITF Coaching and Sport Science Review, 19(55), 11-13.

McCraw, P. D. (2012). Making the top 100: ITF top junior transition to top 100 WTA tour (1996-2005). ITF Coaching and Sport Science Review, 57(20).

Miley, D. (2010). Serve Rally and Score ... . The ITF tennis Play and Stay Campaign and Tennis 10s. ITF Coaching and Sport Science Review, 51(18), 3-4.

Miley, D., \& Nesbitt, J. (1995). ITF Junior tournaments are a good indicator. ITF Coaching and Sport Science Review, 7(12).

Molina, I. (2005). Periodisation in the ITF Junior Circuit, ITF Coaching and Sport Science Review, 13(36), 6. Morris, C. (2005). Periodisation for 18 and under female players. ITF Coaching and Sport Science Review, 13 (36), 7-8.

Patton, M. Q. (1990). Qualitative evaluation and research methods. Newbury Park, CA: Sage.

Perič, T. (2006). Výběr sportovnich talentů. Praha: Grada.

Petlichkoff, L. M. (1993). Coaching children: Understanding the motivational process. Sport Science Review, 2, 48-61.

Porta, J., \& Sanz, D. (2005). Periodisation in top level men's tennis, ITF Coaching and Sport Science Review, 13(36), 12-13.

Reid, M. (2009). Learning from the past - benchmarking player pathways. In Crespo, M., \& Miley, D. (ed.). ITF Worldwide Coaches Conference. Sbornik z védecké konference konané v roce 2009 ve Valencii. Ed. Crespo, M., \& Miley, D. Valencia: ITF, 2009, pp. 32.

Reid, M. a kol. (2005). ITF Junior Boy's Circuit and its role in professional player development. ITF Coaching and Sport Science Review, 13(35), 2-3. 
Reid, M., Quinlan, G., \& Morris, C. (2010). Periodisation in tennis. ITF Coaching and Sport Science Review, 50(18), 26-27.

Reid, M. a kol. (2007). The importance of the International Tennis Federation's junior boys' circuit in the development of professional tennis players. Journal of Sports Sciences, 25(6), 667-672.

Roetert, E. P., Reid, M., \& Crespo, M. (2005). Introduction to modern tennis periodisation, ITF Coaching and Sport Science Review, 13(36), 2-3.

Roetert, E. P., \& McEnroe, P. (2005). Can periodised training work for professional male players? ITF Coaching and Sport Science Review, 13(36), 11-12.

Schnabel, G., Harre, D., \& Borde, A. (1997). Trainingswissenschaft: Leistung - Training - Wettkampf. Berlin: SVB Sportverlag.

Schnabel, G., Harre H.-D., \& Krug, J. (2008). Trainingslehre - Trainingswissenschaft. Aachen: Meyer \& Meyer. Schönborn, R. (1993). Players' performance and development. ITF Coaching and Sport Science Review, $2,1$.

Schumacher, Y. O. a kol. (2007). Erfolg im Spitzenradsport - eine pro- und retrospektive Ranglistenanalyse. Leistungssport, 37(5), 23-28.

Starkes, J., \& Ericsson, K. A. (2003). Expert performance in sports: advances in research on sport expertise. Champaign: Human Kinetics.

Thiess, G., \& Tschiene, P. (1999). Handbuch zur Wettkampflehre. Aachen: Meyer \& Meyer.

Tschiene, P. (1994). Wettkapfpluralität und Adaptation. Leistungssport, 24(5), 9-12.

Unierzyski, P. (2005). Periodisation for Under-14s, ITF Coaching and Sport Science Review, 13(36), 4-6.

Valik, B. (1975). Trenérům mladých atletů. Praha: Olympia.

Vaverka F., \& Černošek, M. (2007). Základní tělesné rozměry a tenis. Olomouc: Univerzita Palackého.

Wiersma, L. D. (2000). Risks and benefits of youth sport specialization: perspectives and recommendations. Pediatr Exerc Sci, 12(1), 13-22.

Woolger, C., \& Power, T. G. (1993). Parent and sport socialization: Views from the achievement literature. Journal of Sport Behavior, 16(3), 171-189.

Young, J. A. (2011). Remember parents and coaches are team members: Team work is required. ITF Coaching and Sport Science Review, 55(19), 17-18. 